\title{
Die Dordtse Leerreëls: 'n Grammatika van geloofstaal gebore uit die nasie-staat-ideologie
}

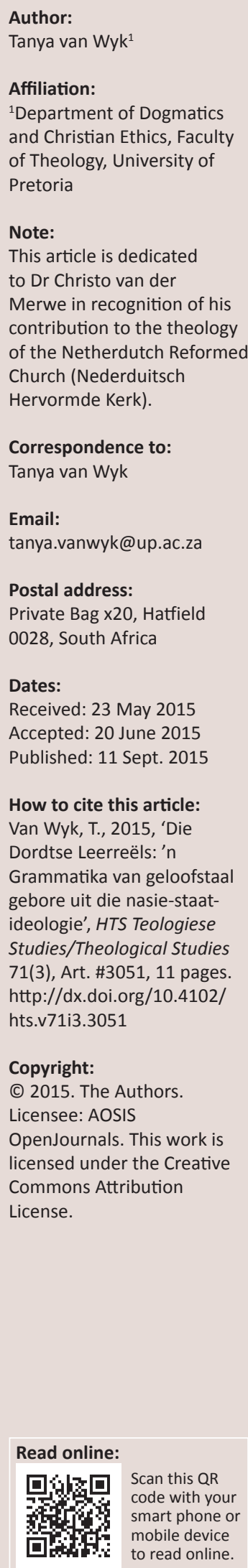

The grammar of faith language in the Canons of Dordt as a result of the nation-state ideology. This article aims to decipher the spirit of the notion 'predestination' codified in the Canons of Dordt. It reconsiders the relevance of these dogmatic propositions about predestination as a grammar of the faith language which originated in a very specific context, namely the political concerns and the religious convictions held in the uniting Dutch provinces as a nation-state. In this context Calvin's views about predestination became instrumental to the establishment of an upcoming nationalistic ideology, based on different interpretations and perceptions of Calvin's theology. Within the context of the Protestant Dutch resistance against the RomanCatholic Spanish-Habsburg hegemony, the Canons were formulated during the Synod of Dordrecht in 1618-1619 as a Calvinistic movement against the Remonstrants who were stigmatised as collaborators of the Spanish-Habsburg reign over the Netherlands. This article demonstrates that different receptions of Dordt heighten the dogmatic gap between the socalled liberal modernism of the Remonstrants and a strict confessionalism of neo-Calvinism which has influenced the present-day understanding of the Canons of Dordt. It is argued that the grammar of the Canons of Dordt needs to be understood against this background and the meaning of the faith language it reflects, interpreted accordingly.

\section{Inleiding: Die Dordtse Leerreëls se 'weeskind'-status}

Van die drie Reformatoriese Formuliere van Eenheid, naamlik die Nederlandse Geloofsbelydenis (NGB), die Heidelbergse Kategismus (HK) en die Dordtse Leerreëls (DL), is 'Dordt' dikwels die 'agtergeblewene' of weeskind wanneer dit by gebruik en verwysing in kerklike praktyk kom. In vergelyking met die sistematiese Nederlandse Geloofsbelydenis en die eksistensiële Heidelbergse Kategismus is die Dordtse Leerreëls abstrak, en vanweë herhaling wat in die teks voorkom, moeilik om te lees (vgl. Jonker 1994:145). In aansluiting hierby is die grootste enkele kwessie wat bydra tot Dordt se 'agtergeblewe status' die etiket van 'n 'verkiezingsfatalisme' (Kamphuis 1988:2). Daarvolgens het God klaar besluit oor die verlossing van elke individu en gevolglik is elke gelowige, sowel as die kerk se etiese en apostoliese imperatief, sonder doel of betekenis. Ten slotte ontstaan daar gevolglik vrae rondom die relevansie en funksie daarvan (Pelser 1999:416) ${ }^{1}$.

Belydenis is 'n gekompliseerde saak. Dit ontstaan in bepaalde kontekste. Dit wat uiteindelik as belydenis (konfessie) neerslag vind, is gegrond op geloofservaring. Die geloofservaring word deur middel van menslike taal en metafore beskryf (Ricoeur 1974:26, 42-43). 'Taal' is die wyse waarop 'ervaring' uitgedruk word. Taal word die 'voertuig' van die 'saak'; dit is geloof gegrond op ervaring. Religieuse taal ontwikkel met ander woorde nie in 'n vakuum nie (Ricoeur 1974:38). Die belydenisskrifte (Reformatoriese Formuliere van Eenheid) is die taal waarin die geloof van die Reformatoriese kerk geartikuleer is. Wanneer die ontstaanskonteks en -geskiedenis van belydenisskrifte buite rekening gelaat word, is die gevolg 'n verstarring in die verstaan en gebruik van belydenisskrifte wat in 'n onkritiese konfessionalisme of onkritiese liberalisme ten opsigte van die interpretasie en handhawing van belydenis (en die belydenisskrifte) ontaard. Deur 'eksegese' van belydenisskrifte, soos die geval is met Bybelse tekste, kan die saak wat in die teks geartikuleer word, as't ware 'vertaal' word. En hierdie 'vertaling' eindig nie by een van die genoemde terminusse nie, te wete onkritiese aanvaarding (of toepassing) of 'n onkritiese tersydestelling vanweë 'n sogenaamde gebrek aan relevansie. Of anders gestel: die lees en handhawing van belydenisskrifte kom nie neer op 'n keuse vir óf geloof óf kennis (rede) nie. In hierdie artikel word hierdie saak ten opsigte van die Dordtse Leerreëls ondersoek en die relevansie daarvan uiteengesit.

Hierdie artikel word aan dr. Christo van der Merwe opgedra. As predikant van die Nederduitsch Hervormde Kerk (NHKA) en later hoof van die Hervormde Teologiese Kollege (2012-2014) (HTK),

1.Pelser (1999:416-417) bespreek hierdie kwessie nie net in terme van die Dordtse Leerreëls nie, maar ten opsigte van die belydenisskrifte in die algemeen. 
het hy homself beywer om saam met verskillende geslagte kerklidmate, en later ook studente, na te dink oor die wyse waarop kontekstuele veranderinge - en verskuiwings - die kerk uitdaag om met integriteit kerk te wees. In hierdie taak het hy erns gemaak met die karakter en etos van die Hervormde Kerk en het hy 'n reusebydrae gelewer deur navorsing vanuit sy vakgebied, Praktiese Teologie, oor die aard van kerkwees en die missionale gerigtheid van die kerk (vgl. Van der Merwe 1997, 2013, 2014). Hy is die lewende beliggaming van die 'Hervormde gees' waar kennis nie kennis is nie as dit nie ook vertroue in God is nie, en vertroue nie vertroue is nie as dit nie kennis van die Heilige Skrif is nie.

\section{Die eksegese van die Dordtse Leerreëls}

Die eksegese en toepassing van belydenisskrifte is nie anders as dié van die Bybel nie. Opsommend gestel, beteken dit ten minste dat (1) die tekste (bedoelende in hierdie artikel die belydenisskrifte) in verband met die geheel uitgelêword, en nie in isolasie nie; (2) die historiese ontwikkeling van tekste in ag geneem word; (3) die historiese (godsdienshistoriese, politieke en sosiologiese) konteks (verwysend na gedeelde waardes) nie buite rekening gelaat word nie; (4) die sistematiese 'gees' van die boodskap wat deur die tekste gekommunikeer word, ernstig opgeneem word en dat daar nie op ongekontroleerde wyse eie vooroordele in die betekenis daarvan ingedra word nie; (5) die 'werkingsgeskiedenis' (resepsie of ontvangs) van die invloed in die latere kerkgeskiedenis, hoewel belangrik om daarvan kennis te neem, nie gelyk gestel word aan die gekommunikeerde boodskap in die oorspronklike konteks nie; en (6) dat die verskil in kultuur en in tyd tussen die tyd toe die tekste ontstaan het, en die kultuur en tyd waarin die lesers/uitleggers/kerklike gemeenskap hulle vandag bevind, baie ernstig opgeneem word. Hieroor is daar in die teologie geskiedenisboeke vol geskryf en dit is steeds 'n uiters gekompliseerde aangeleentheid (vgl. o.a. Pelser \& Van Aarde 2007:1377-1411). Hierby moet in ag geneem word dat die dogmatiese studie van tekste vir kerklike gebruik die bedoeling behoort te hê om die geloofstaal, die hart van die boodskap daarvan, vir vandag se gelowiges te 'vertaal'.

\section{Dordt en die nasie-staat: Die godsdienshistoriese, politieke en sosiologiese konteks}

Eksegese van die Dordtse Leerreëls behels 'n komplekse wordingskonteks en resepsiegeskiedenis wat in verband staan met die konteks waarin die ander Reformatoriese Formuliere van Eenheid, te wete die NGB in 1562 en die HK in 1563 ontstaan het. Hierdie konteks is 'n mengsel van religieuse (godsdienstige) oortuigings en nasionalistiese motiewe. Die stryd tussen Protestante en Rooms-Katolieke was nie net religieus van aard nie, maar ook polities ${ }^{2}$. Die Protestante

\footnotetext{
2. In die ontstaan van die Duitse nasie-staat het die 'vereniging' (in plaas van 'selfstandigheid') van die suidelike Rooms-Katolieke 'klein Duitsland' (vandas se Oostenryk) met die noordelike Protestantse 'groot Duitsland' 'n wesenlike se Oostenryk) met die noordelike Protestantse 'groot Duitsland' ' $n$ wesenlike
rol gespeel (Clarke 2008). Tadeusz Kugler (2015:247) meen dat hierdie 'politieke teologie' steeds vandag ' $n$ nadelige uitwerking het.
}

is deur die Spaanse (Rooms-Katolieke) koningshuis vervolg gedurende dieselfde periode waartydens Europese nasiestate tot stand gekom het (Van Wyk 2014:2 van 10; vgl. Moxnes 2012:3-4). Die godsdiensstrewe van beide Protestantisme en Rooms-Katolisisme is wesenlik beïnloed deur die opstandigheid van die burgerlike middelklas (bourgeois) teen koninklike finansiële uitbuiting (wat 'n klimaks in die Franse Revolusie van 1787-1799 bereik het) en die vestiging van republikeins-demokratiese regerings. Met die ontwaking van nasionalisme in hierdie tyd het gefragmenteerde streke (provinsies en hertogdomme) tot groter politieke eenhede (nasiestate) ontwikkel en die institusionele kerk as 'n soort 'staatskerk'. In die periode 1568-1648 het die Nederlanders (ingesluit die Belge), bestaande uit 17 provinsies, in opstand gekom teen koning Philippus II van Spanje wat ook die regeerder van die (Oostenrykse) Habsburg monargie was. Hy het deur middel van 'n Rooms-Katolieke kontraReformatoriese magsgreep oor die Nederlande geregeer (kyk Pettegree 2002:214). Karel die Grote, keiser van die 'Heilige Romeinse Ryk' - dit was die kerk en staat in een, hoewel Rooms-Katoliek - het in 1555 verskillende streke van die keiserryk aan ondergeskikte konings oorgedra en die koning van Von Habsburg, Philippus II, seun van Karel die Grote, was in beheer van onder meer die 17 Nederlandse provinsies geplaas.

Willem (die Swyger) het, vanuit die trans-Nederlandse gebied in Protestantse Noord-Duitsland (Emden), die opstand van die Nederlanders teen die Spaans-Habsburgse oorheersing gelei en in 1581 die 'Republiek van die sewe Verenigde Nederlande' gevestig. Dit was die begin van die Oranje-dinastie en die Protestantse nasie- of (volks-) kerk in Nederland. Die oorlog en vervolging teen die Protestante het verwoed voortgeduur. Spanje-Habsburg het van die inwoners van al die 'Spaanse' gebiede konformisme met die Rooms-Katolieke Kerk (RKK) geëis. Die RKK se ekklesiologie het nie ruimte gelaat vir die moontlikheid dat mense gelowig kan wees buite om die 'Roomse denominasie' nie (extra ecclesiam nulla salus). Eers tydens die Tweede Vatikaanse Konsilie (1962-1965) is van hierdie eksklusiwisme formeel afstand gedoen.

Die Dordtste Leerreëls is gegrond op die Nederlandse Geloofsbelydenis en die Heidelbergse Kategismus ${ }^{3}$ (alhoewel in ' $n$ mindere mate as op die NGB). Die NGB wat in 1561 beslag gekry het, was in 'n sekere sin 'n pleitskrif aan die Spaans-Habsburgse koningshuis. Dit is op 01 November 1561 oor die mure van koning Philippus II se kasteel in Doornik (die hedendaagse België) gegooi, sodat dit fisiek in die hande van die koning kon beland (vergelyk Blei 2006:11). Dit was ' $n$ 'pleitskrif' om die vervolging teen die Protestante te staak en te besef dat die Reformasie en die RKK dieselfde ekumeniese geloofsbelydenisse (Apostolicum, Nicenum

3.Daar is verskillende vakwetenskaplike insigte hieroor. R.T. Kendail (1979) het geargumenteer dat die Heidelbergse Kategismus afgewyk het van suiwer Calvinistiese standpunte en dat die Heidelbergse Kategismus 'verraad' teenoor Calvyn is (Kendall 1979:210; kyk Dreyer 2014:4 van 5). Stephan Thorson (1994:413-426), vanuit die evangelikaalse tradisie (wat verband hou met die paradigma waaruit Kendall argumenteer), en Alisdair Heron (1980:25), vanuit die evangelikaals Kendall argumenteer), en Alisdair Heron (1980:25),
Calvinistiese tradisie, is dit egter nie met Kendall eens nie. 
en Athanasianum) het. Dit is opgestel onder leiding van (die Belgies-Franse Hugenoot) Guido de Bres, wat ses jaar later ter dood veroordeel en opgehang is, omdat hy nie die Protestantse geloof wou afsweer nie.

Die Heidelbergse Kategismus, wat in 1563 beslag gekry het, ontstaan in Duitsland in 'n soortgelyke konteks, naamlik een van stryd tussen Protestante en Rooms-Katolieke, toegespits op die Lutherse Reformasie. Die Heidelbergse Kategismus (Confessio Augustana - vergelyk Landau 2010:326) ${ }^{4}$ verteenwoordig egter' $n$ 'sagter' gees as die Dordtse Leerreëls, wat tussen die jare 1578-1619 vanuit NoordDuitsland en die Verenigde Nederlande geïnspireer is. In die Bo-Rynse gebied Kurpfalz het keurvors Frederick III (15591576) gereageer op die RKK se Konsilie van Trent/Bologna (1545-1563) wat met 'n kontra-Reformasie 'n alternatief vir die 'kettery' van die Reformasie (veral Lutherane) wou bied $^{5}$. Die groot kwessie wat tot die Reformasie gelei het en dwarsdeur die wordingsgeskiedenis van die drie Formuliere van Eenheid aanwesig is, is die leer van die Reformatore (hervormers) omtrent die 'passiewe ontvangs van genade' teenoor die Rooms-Katolieke Kerk se standpunt dat God se regverdigheid in samewerking met die mens geskied. Hierdie kwessie is bevestig by die Konsilie van Trent (Bierma 2013:5). Die konsilie het voortgebou op die Rooms-Katolieke standpunt dat die hervormers te veel waarde heg aan die futiliteit van menslike vertroue. Hierop het die Heidelbergse Kategismus, veral na aanleiding van die hervormer Philippus Melanchthon (1497-1560) se 'humanitêre' insigte, in Sondagsafdeling 7, vraag en antwoord 21, met 'n regstelling geantwoord dat 'ware geloof' inderdaad op twee pilare staan, te wete, (1) die insig in wat die Heilige Skrif leer, maar ook (2) die 'vaste vertroue' van die mens op grond van die inspirasie van die Heilige Gees.

In 1552 is die Konsilie van Trent onderbreek toe die Protestantse keurvors van die Sakse, Mauritz (Moritz), wat sterk gekant was teen die (Rooms-Katolieke) imperiale dominansie van Karel (V) die Grote, die gebied van Tirol (waar Trento en Bologna geleë is) militêr verower het. Tog het 'n gees van relatiewe verdraagsaamheid van beide die Protestante en die Rooms-Katolieke jeens Mauritz, op grond van sy suksesvolle militêre veldslae teen die Ottomane, veral in Hongarye, begin posvat. Die 'gees' van die HK het ongetwyfeld tot hierdie verdraagsaamheid bygedra. Onverdraagsaamheid het egter weer opgevlam namate die nasiestate begin ontwikkel het (Van Wyk 2014:2 van 9), en die nasionale strewes verstrengel geraak het in of Protestantse of Rooms-Katolieke godsdienstige ideale. Dit kan gesien word in ' $n$ aspek van die wordingsgeskiedenis van die DL wat soortgelyk is aan dié van die HK, maar vanweë verskillende kontekste anders uitgekristalliseer het, naamlik die wyse waarop diverse standpunte gehanteer is.

4.Volgens Peter Landau (2010:385) het hierdie 'Heidelbergse vrede' nie net staatsregtelik bygedra tot die bevordering van die prinsipes 'pariteit' en 'toleransie' nie, maar ook verdraagsaamheid jeens belydenisse van ander denominasies.

5.Dit was veral met betrekking tot die onderskeid tussen die Heilige Skrif en heilige tradisie, die erfsonde, die regverdigheid van God en die bemiddelende rol van heiliges.
In 1612 (ongeveer 50 jaar na die formulering van die NGB en die HK onderskeidelik) breek 'n 12-jarige vredestydperk te midde van die Nederlandse onafhankliksoorlog aan. Die RKK het steeds die uitverkiesing van gelowiges beperk tot die Heilige Romeinse Ryk. Waar die ontstaanstyd van die NGB te midde van die eerste fase van die 80 -jarige oorlog was en gefokus het op die ooreenkomste en verskille tussen die Reformatoriese geloofsleer en dié van die RKK - asook dié van die 'Wederdopers' (Anabaptiste) - was die ontstaanstyd van die DL dié van die 'vrede' tussen die Nederlandse opkomende nasie-staat en die Spaans-Habsburgse koningshuis, maar wel 'n tydperk van binnekerklike konflik tussen Gereformeerde 'Calviniste' en Remonstrante. In dié 'vredestyd' ontstaan daar twee stromings binne die Protestantse kring, naamlik 'n streng navolging van Calvyn se leer en die tradisie wat daaruit ontwikkel het ('Calviniste') en 'n minder streng of gematigde navolging van Calvyn se leer en die tradisie wat weer dááruit ontwikkel het ('Remonstrante'). Die Calviniste en die Remonstrante het hulle beide beroep op Artikel 36 van die NGB wat gestel het dat die Reformatoriese godsdienstige tradisie deur die staat beskerm en bevorder moes word. Die Kerkorde van Dordtrecht het later, soortgelyk as die vroeëre Calvinistiese 'ordes' (soos Emden, opgestel in 1571, en Middelburgh, opgestel in 1586), die nuwe Artikel 28 ingevoeg wat van kerklike ampsdraers vereis om aan die staat (wat as 'n 'Christelike regering' geag is) gehoorsaam te wees en van die staat te verwag om sekuriteit en rustigheid in die samelewing te handhaaf sodat die kerk in staat kan wees om gehoorsaam te wees (Blei 2006:33-36).

Die verskil ten opsigte van die stromings binne die Protestantse kring het ingetree oor verskille in hoe die kerk se rol ten opsigte van die interpretasie en die handhawing van kerkleer geïnterpreteer en verstaan behoort te word (Jonker 1994:123-124). Konflik binne die Protestantse kring het ontstaan oor die verskil van wat God se uitverkiesing sou beteken. Die groep bekend as die Remonstrante, wat sterk deur die Leidense professor Jacob Armenius beïnvloed is, het begin leer dat die mens 'n vrye wil het om te besluit of sy/hy God se genade-aanbod wil aanvaar of nie en, indien wel, weer later kan besluit om dit nie meer verder te aanvaar nie (kyk Goudriaan 2011:81-106). Armenius was veral deur sy Calvinistiese kollega professor Franz Gomarus geopponeer (vgl. Walker 1970:399). Die Remonstrante is deur die 'Calviniste' as beweerde kollaborateurs van die RKK gestigmatiseer. So byvoorbeeld word in 'n brief van baron Franciscus (François) van Aarssens (1572-1641) - 'n politikus wat 'n belangrike rol in die onderhandelings rakende die twaalfjarige wapenstilstand gespeel het (VU University of Amsterdam [1607] 2009) - die bewering aangetref dat die Armeniane (Remonstrante) met koning Philippus IV van Spanje saamgesweer het. Dit was 'n valse persepsie, hoewel verstaanbaar teen die agtergrond van die Nederlanders se strewe na vryheid.

Die rede vir hierdie beskuldiging deur die Calviniste was waarskynlik omdat die Remonstrante se verstaan van uitverkiesing en die mens se aandeel daarin vir die Calviniste na bewering gevaarlik naby aan RKK teologie gekom het. Die 
RKK beklemtoon óók die mens se aandeel in God se genade en uitverkiesing, maar op ' $n$ totaal ander wyse in die vorm van die sogenaamde 'werkheiligheid'. Vir die Remonstrante het dit om die menslike vryheid om te kies gegaan. Vir die RKK het dit daarom gegaan dat die mens, deur 'die goeie' te doen (die verband tussen geloof en werke), in staat is om God se 'uitverkiesing'/'genade' te bewerkstellig. In die lig van die verbete stryd van die Nederlanders teen die seun van Karel V, Philippus II van Spanje-Habsburg, is eksklusiwisme egter op die spits gedryf en het die uitverkiesingleer in 'n teologiese instrument ten dienste van eksklusiewe nasionalisme ontaard.

Dit is ongelukkig dat die oomblik toe die stryd en vervolging na buite tydens genoemde 'vredestydperk' opgehou het, die stryd en vervolging na binne ingetree het. Diverse religieuse oortuigings (oor Calvyn se leer) en nasionale motiewe het in vyandelike groeperings omgesit. Dit is interessant dat die konteks waarin die HK ontstaan het 'n soortgelyke diversiteit ten opsigte van die interpretasie van Maarten Luther se leer gehad het. Na Luther se dood het Duitse Lutherane ' $n$ skeiding ondergaan: die Gnesio-Lutherane (wat Luther se 'suiwer' leer verdedig het) en die Melanchtoniane (Phillipists) wat sekere aspekte van Luther se aanvanklike leer aangepas het ter wille van ekumeniese verdraagsaamheid. Philippus Melanchthon het vir 'n soortgelyke toleransie en verdraagsaamheid ten opsigte van die interpretasie van Maarten Luther se leer gepleit ${ }^{6}$ soos die Remonstrante ten opsigte van Calvyn se leer gepleit het, en tog is sy insigte wesenlik deel van die uiteindelike formulering van die HK (Bierma 2013:4-5). Omdat die HK egter in 'n konteks ontstaan het waarin Protestante gesamentlik onder RoomsKatolieke vervolging gebuk gegaan het (Duitsland), was 'n meer gematigde interpretasie van die leer (Luther s' $n$ in hierdie geval) wenslik om bepaalde uitkomste te bereik. Toe vervolging van die Protestante in 1612 tydelik tot 'n stilstand kom, blyk dit dat die onverdraagsaamheid as Protestantse 'binnegevegte' voortgesit is, en dit was die konteks waarin die DL ontstaan het.

\section{Die Sinode van Dordtrecht}

Die Nederlandse politikus Johan van Oldenbarnevelt (1547-1619), het aanvanklik steun geniet toe hy met RoomsKatolieke Spanje ' $n$ handelsverdrag ten opsigte van die 'OosWes Indiese' gebiede in die Karibiese See gesluit het. Maurits, prins van Oranje - ook 'n militaris - het weerstand teen Van Oldenbarnevelt, 'n sterk Remonstrantse ondersteuner, gebied. Dit was Maurits wat die direkte stimulans was vir die Nasionale Sinode van Dordrect wat op 13 November 1618 begin het (Fix 1991:33-34). Een van Maurits se predikante was Uytenbogeart, uit die koninklike familie van Oranje en ook 'n voorstander van die sogenaamde liberale oortuiging dat die mens ' $n$ vrye wil in God se genade-aanbod het. Maurits se weersin teen sy predikant gee aanleiding daartoe dat hy homself met 'n eed aan Calvinisme verbind op grond van sy interpretasie van Calvyn se leer.

6.Philippus Melanchton het as 'n 'brugbouer' opgetree (kyk Van der Pol 2011).
Die brief van baron Franciscus van Aarssens aan Johannes Uytenbogaert dat die Remonstrante aan hoogverrad skuldig sou wees omdat hulle na bewering met die Rooms-Katolieke oorheersers sou saamwerk, het stukrag vir die idee van 'n 'nasionale' sinode gebied. Die doel van die sinode sou wees om die dispuut tussen die Calviniste en die Remonstrante by te lê. Die Remonstrante het wat volgens hulle 'n pessimistiese mensbeeld was, verwerp en het om sosio-politieke redes die fokus op die waardigheid van die mens geplaas. Die meer ortodokse Protestante (neo-Calviniste) ${ }^{7}$ wou die invloed van die Remonstrante in die sinodesitting teenwerk (Clarke 2008; Schaff 1983:515; vgl. Van Wyk 2012: bl. 3 van 9). Hulle wou gevolglik die sinode tot die provinsie Holland beperk, waar hulle neo-Calvinisme sterk invloed gehad het, maar die Remonstrante het op 'n nasionale sinode aangedring. Dit was deur bemiddeling van die Engelse ambassadeur Dudley Carleton dat daar in 1617 op 'n nasionale sinode besluit is.

Dit is amptelik as 'n 'ekumeniese' sinode georganiseer, met enkele afgevaardigdes uit Europa, Engeland en Skotland. Aanvanklik was 14 Remonstrante teenwoordig. Simon Episcopius het namens die Remonstrante opgetree en het gemeen dat die bespreking tydens die Sinode met 'n meer gematigde saak, naamlik 'reprobasie' (die leer van afvalligheid nadat iemand gedoop en deel van die nasionale volkskerk geword het), begin moet word. Die Calviniste (neoCalviniste) was nie daarvoor te vinde nie en gevolglik het al die Remonstrante die Sinode verlaat. Episcopius (en andere) wou toe wel ondersteuning van die verteenwoordigers van die Anglikaanse afgevaardigdes kry en dit het op 'n lang prosedurekwessie-vergadering uitgeloop. Op 14 Januarie het die 57ste sessie van die Sinode begin (daar was 154 sittings vanaf 13 November 1618 tot 9 Mei 1619), en die Remonstrante is die vergadering verbied. Hulle het hulle ampsvoorregte verloor. Tog het die Remonstrante besluit om voort te gaan met die bediening van hulle ampsvoorregte, hoewel alleen in kerke (gemeentes) waar die staat die traktemente van predikante van die Nederlandse Hervormde Kerk betaal het.

Die sinode se uitkoms was daarop gemik om die ortodokse oortuigings teenoor die Remonstrante se interpretasie van Calvyn se leer duidelik te maak. Die ortodokse oortuigings is saamgevat in 5 stellings, verwysende na 'total depravity', 'unconditional election', 'limited atonement', 'irresistible grace' en 'perseverance of the saints', oftewel, 'T.U.L.I.P.' (Sinnema 2011:87-103; vgl. Van Wyk 2012:2). Dit het daarop gedui dat:

\footnotetext{
7.Die ontstaan van twee verskillende groepe volgelinge van Calvyn in Nederland he tussen 1586 en 1619 'n historiese werklikheid geword. Bakhuizen van den Brink en Dankbaar (1967:276) verwys na die onderskeie groepe vanuit die perspektie van dié wat die konfessie 'strenger' wou handhaaf, dit wil sê die ortodokse neo-Calviniste, as 'preciezen' en 'kerkelijken' teenoor die ander 'rekkelijken' en 'politieken' (vgl. Coertzen 2012:79). Eersgenoemde is in die Gereformeerde en laasgenoemde in die Hervormde tradisie gekontinueer. Die Gereformeerdes het Artikel V van die Kerkorde Van Dordrecht se bepaling van die 'plaaslike outonomie' van die gemeente as kerk (kyk Blei 2006:17, 37) as sentraal tot kerkorganisasie be in reken begin reken na aanleiding van die , begrip 'vrye kerk'. Vir die Hervormdes was verdraagsaamheid jeens diversiteit 'n belangrike kenmerk van kerkorganisasie en is 'n gemeente a belydende (volkskerk/verbondskerk) en ook van die algemene Christelike kerk. Die NHKA het reeds by twee Algemene Kerkergaderings met ' $n$ meerderheid besluit om die begrip 'volkskerk' nie meer te gebruik nie. Sodoende sal die etiket 'politieken' finaal wegval, maar die karakter van die Hervormde Kerk as 'rekkelijk' (tolerant vir verskeidendheid) kontinueer.
} 
- alle mense is verlore

- Jesus Christus sterf vir alle mense

- geen mens kan hierdie genade uit eie vermoë aanvaar nie, maar elkeen wat dit nie wil aanvaar nie, kies self om dit te verwerp

- geen mag in hemel of op aarde kan God keer om die uitverkorenes uit geestelike dood na geestelike lewe te bring nie

- die uitverkorenes kan nie weer afvallig word nie en word voortdurend deur woord en sakrament aan die genade herinner. (Sinnema 2011:87-103; vgl. Jonker 1994:132-133)

Die uiteinde van die Sinode van Dordrecht was nie net die opstel van die DL nie, maar ook later die Kerkorde van Dordt en die Statevertaling van die Bybel. Daarmee saam is predikante verplig om hulleself deur ondertekening aan die 'Handeling van Ampsverlies' - vandag se proponentsondertekeningsformule - te verbind. Dit het met die ondersteuning van die 'State-Generaal' plaasgevind. Diegene wat nie wou nie, is uit die Verenigde Nederlandse Republiek verban. $\mathrm{Na}$ aanleiding van die stelling vroeër in die artikel dat religieuse oortuigings en nasionalistiese motiewe saam die wordingskonteks van die Reformatoriese Formuliere van Eenheid gevorm het, het dit na afloop van die Sinode van Dordrecht geblyk dat religieuse ekskommunikasie en verlies van nasionale burgerskap twee kante van dieselfde muntstuk was. Johan van Oldenbarnevelt is aan dwaalleer en politiek onetiese gedrag skuldig bevind, omdat sy religieuse oortuigings die nasie in wanorde sou gedompel het. Een van sy ondersteuners, die juris Hugo Grotius, is vanaf 29 Augustus 1618 tot lewenslange gevangenisstraf gevonnis.

\section{Dordt se Wirkungsgeschichte}

Die etiese of praktiese uitvoering van die inhoud van die Sinode van Dordrecht, naamlik die wyse waarop diegene (almal) wat uitverkies is, hulle lewe op grond van evangeliese waardes behoort in te rig, is nie tydens die sinodesitting van Dordrecht uitgewerk nie. Hierdie ontbrekende etiese aspek is eers by 'n latere sinode in 1632 in Dordrecht toegevoeg. By hierdie sinode is die 'Konfessie van Dordrecht', wat bestaan uit 32 artikels, opgestel. Hierin is die kerk se barmhartigheids- en sosiale taak ondubbelsinnig uitgespel (Van Wyk 2012: 2 van 9). Die 'Konfessie van Dordrecht' het 'compassion, tolerance and spiritual guidance' (Harder 1995) beklemtoon.

In terme van die eksegese van die DL is dit belangrik dat die 1618/19-sinode se uitkomste nie sonder die 1632-sinode se verklaring en verheldering gelees en geïnterpreteer word nie; dit is die latere sinode wat die 'saak' van Dordt (1618/19) beklemtoon het deur die etiese implikasies en imperatief daarvan vas te stel. Legalisme en 'n letterlike biblisisme (Harder 1995) het nie deel hiervan uitgemaak nie.

In die DL (en in die NGB) is geloofsoortuigings die goue draad wat deur beide loop. In die NGB, wat 44 jaar ná Luther se hervorming in 1517 beslag gekry het, is die goue draad die volgehoue geloofsoortuigings van Hollanders teen die agtergrond van bittere vervolging van (die Spaanse) RoomsKatolieke Kerk ('n soortgelyke konteks is ter sprake by die opstel van die HK). In die DL, wat beslag gekry het 56 jaar ná die NGB, is die goue draad die volhouding van hierdie geloofsoortuigings te midde van die 12-jarige 'skietstilstand' tussen die 'verenigde Nederlanders' (dit is, die Hollanders en Vlaminge) en die Spaanse (Rooms-Katolieke) koningshuis. Hierdie skietstilstand het in 1619 tot 'n einde gekom.

Die verskil in nuanse tussen die NGB en die DL is gesetel in die bron van die geloofsoortuigings. Die bron van die geloofsoortuigings soos dit in die NGB verwoord is, is die kanonieke geskrifte van die Reformatoriese (LuthersCalvinistiese) Bybel. Met die NGB wou die Protestante in die Verenigde Nederlande vir die Roomse 'nasionale/ staatskerk' sê dat die geloofsbelydenis alleen in die Bybel te vind is (vgl. veral Artikels 3-7 van die NGB) en dat geloof nie deur die kerklike instituut gereël word nie. In die DL is die bron van die geloofsoortuigings die geestelike en nasionale ruimte van die kerk as instituut - en hierdie ruimte is wesenlik verbind met die land van die Verenigde Nederlande - eers 'n republiek en toe 'n koningshuis. In 1648 word die Nederlandse Republiek as onafhanklike staat erken. Die beëindiging van Spaanse tagtigjarige oorlog in 1648 het gelei tot die Verenigde Nederlandse Provinsies en dit het in die negentiende eeu 'n konstitusionele monargie ${ }^{8}$ geword.

Trouens, die Sinode van Dordrecht het amptelik as die Synodus Nationalis Dordrectanae bekendgestaan. Dit het beteken dat 'uitverkiesing' beperk word tot die 'belydende volkskerk', dit wil sê die verbond van gelowige huisgesinne, deur God byeengeroep op grond van die doop, en 'ordelik' bestuur deur middel van die nagmaalsformulier. ${ }^{9}$ Die DL kan dus nie los van die Kerkorde van Dordrecht verstaan word nie. Hierdie kerkorde het egter nie die basis van die Nederlandse Hervormde Kerk (en ook die Nederduitsch Hervormde Kerk van Afrika) gevorm nie, maar wel in die beginjare van die Gereformeerde Kerke in Nederland en tot vandag toe van die Gereformeerde Kerke in Suid-Afrika (kyk Vorster 1999:383). In die Nederlandse Hervormde Kerk, sedert die vorming van die monargie onder koning Willem 1, het die Algemeen Reglement van 1816 die orde van die kerk as 'protestantse nasie' deur 'n 'genootschappelijke' (kollegiale) karakter gekenmerk (Clemens 1998:145-176). Hiervolgens is die organisasie van die kerk by die staatsregtelike situasie aangepas (kyk De Groot 1993:119).

8.Die begrip 'nasie' het in Engeland, Frankryk en Duitsland'n parallelle geskiedenis met dié in Nederland, hoewel met unieke karaktertrekke. In die Verenigde Nederlande het Prins Willem I (1533-1548), dit wil sê 'Willem die Swyger') van die provinsie Oranje-Nassau'n soortgelyke rol as Otto von Bismarck in Pruisiese Duitsland vervul. Hy het voortdurend protes aangeteken teen vreemde oorheersers in Nederland. Dit het gelei tot die konstitusionele monargie wat in 1815 onder Willem Frederik VI begin is. Laasgenoemde het na homself as Willem I begin verwys, hoewel die geskiedenis van die Oranje-dinastie met Willem de Zwijger begin het. Dié Willem I is gebore op 24 April in 1533 en is op 10 Julie 1584 in Delft vermoor weens instigasie deur die Spaanse koningshuis. Hy het deurgaans simpatie met die vervolgde Franse Hugenote en Nederlandse Calviniste gehad en het self in 1573 'n Calvinis geword (vgl. Van Wyk 2012). 9.Vergelyk die doktorale proefskrif van Nicolai H. Bijleveld, 2007, 'Voor God,
volk en vaderland: De plaats van de hervormde predikant binnen de nationale volk en vaderland: De plaats van de hervormde predikant binnen de nationale Ph.D.-proefskrif, Universiteit van Groningen. 
Die bestendiging van die idee van 'n 'volkskerk' is hiermee versterk. ${ }^{10}$ Die Kerkorde van Dordrecht het die 'soewereiniteit in eie (kerklike) kring' gepropageer. Hierdie ontwikkelings is die resultaat van die wyse waarop twee verskillende interpretasies van Calvyn se leer (via die DL) op twee verskillende wyses ontwikkel het.

\section{Twee bane van ontwikkeling wat hulle oorsprong by Dordt het}

Jonker (1994:145) is van mening dat daar 'n formele swakheid in die Dordtse Leerreëls aanwesig is, wat bestaan uit lomp formulering, herhaling en 'n opstapeling van 'Remonstrantse dwalings' wat verwerp word. Hy meen dat hierdie problematiese formulering direk in verband staan met die konteks waarin dit ontstaan het, naamlik 'n stryd waarin partye teenoor mekaar te staan gekom het. Te midde van hierdie stryd het die saak waaroor die onderskeie partye verskil het, naamlik die verstaan van uitverkiesingsteologie, te midde van verskillende interpretasies en formulerings 'n instrument geword waarmee daar in die geheel onkrities omgegaan is.

Daar was twee resepsies op Calvyn, wat onderskeidelik by die opstellers van die DL en die Remonstrante gesien kan word. Beide is verder ontwikkel en het aanleiding gegee tot verskillende teologiese strominge wat steeds in die een en twintigste eeu van krag is. Die een interpretasie en ontwikkeling van Calvyn se leer, wat by die opstellers van die DL ontstaan het, het aangesluit by Calvyn se verstaan van God se soewereiniteit. Die ander interpretasie en ontwikkeling van Calvyn se leer, wat by die Remonstrante ontstaan het, het aangesluit by Calvyn se siening van die 'afvallige' (reprobate) en kon gevind word in Episcopius se pleidooi in sy openingsrede by die Sinode van Dordrecht.

Nadat die Remonstrante hulle ampsvoorregte ontneem en gedwing is om die Universiteit van Leiden te verlaat, het hulle hulle na Antwerpen gewend wat gedurende daardie tyd onder Spaanse beskerming was. Die Remonstrantse Broederskap het op 30 September 1619 tot stand gekom. Simon Episcopius, Johannes Uytenbogaert en Nicolaas Grevinkhoven was as organiseerders van 'n 'nuwe kerk' benoem (Fix 1991:36). Die Broederskap het hulle beywer vir 'n terugkeer na die plek waar hulle teologie ontstaan het, naamlik Leiden. Uytenbogaert (predikant van prins Maurits) wat een van Armenius se tydgenote was, het 'n wesenlike rol gespeel in die opbou van die 'Broederskap'

10. Hoewel Pont aandui dat hierdie soort "genootskap" oorgeneem is in die Voortrekkers se geloofsgemeenskap, het hy op teensprekende wyse aan die een kant op 'Gereformeerde' (Pont 1986:47) neo-Calvinistiese wyse beswaar teen dié soort kollegialiteit omdat dit die plek van die konfessie onderspeel, maa aan die ander kant, anders as die neo-Calviniste, bou hy sy beswaar teen die gees van die Algemeen Reglement van 1816 daarop dat dit 'n 'wig slaan tussen kerk en volk' (Pont 1986:69). Hierteenoor argumenteer Blei (2006:99) dat die Nederlandse Hervormde Kerk juis op grond van die 'genootskappelike' karakter van die Algemeen Reglement (soos geamendeer in 1852) - anders as die gees van van die Algemeen Reglement (soos geamendeer in 1852) - anders as die gees van die Kerkorde van Dordrecht - as 'volkskerk' gemanifesteer het. Dit is daarom dat Dreyer (2006:1337-1368) van oortuiging geraak het dat die term 'volkskerk' in sowel teologiese as praktiese sin betekenis verloor het - ook vir die Nederduitsch Hervormde Kerk van Afrika - omdat die werklikheid van die verhouding kerk/staat in die hedendaagse gesekulariseerde werreld heeltemal anders daar uitsien as tydens die ontwikkeling en bevestiging van die nasie-staat-idee in die agtiende en negentiende eeu. in die tydperk toe dit ontstaan het. In 1652 is Maurits na sy afsterwe deur sy broer, Frederick, opgevolg wat simpatiek teenoor die Remonstrante was, maar ook versigtig was om diegene wat kontra die Remonstrante was, te akkommodeer. Uytenbogaert kon dus in 1632 weer begin preek. Gedurende hierdie tydperk was die Broederskap in die verenigde provinsies as 'n 'nie-amptelike kerk' werksaam. In 1634 is die Remonstrantse kweekskool in Amsterdam gestig, en Episcopius was die eerste hoof van dié kweekskool. In 1668 is hy deur Etienne de Courcelles en later deur Phillippus van Limborch in 1712 opgevolg.

In voorbereiding vir die 1618-sinode word Remonstrantse predikante van die provinsie Holland (in Delft) uit hulle amp onthef. Gijsbert van der Kodde, 'n ouderling van die gemeente van die dorp Warmond, word deur die gemeente gevra om die gaping te vul. Die gemeente wou nie iemand van die kontra-Remonstrante as predikant toelaat nie. Die gemeente onder leiding van Van der Kodde het die Kollegiale Beweging (Collegiant Movement) gevorm (Fix 1991:40).

Die stroom wat Calvyn se verstaan van God se soewereiniteit en die 'dubbele uitverkiesingsdogma' beklemtoon het, het gekulmineer in die neo-Calvinisme (vgl. Van Eijnalten 2003:127-128), en het onder Abraham Kuyper (1837-1920) volledig vorm aangeneem. Teen die agtergrond van die nawerking van die Franse Revolusie vervul hy 'n belangrike plek in die Nederlande se kerkpolitiek. Kuyper het'n politiesdenominasionele apartheid in die samelewing voorgestaan waarvolgens Protestant, Katoliek (en enigiemand anders) elkeen eie skole, universiteite en sosiale organisasie sou hê. Hy pleit vir die skeiding tussen staat en kerk en het die sentralisasie van die kerk en die rol van die koning teengestaan (prorepublikeins en antimonargaal) ${ }^{11}$.

Sedert 1815, toe Willem Frederik VI die eerste koning van die Verenigde Nederlande geword het, heg die konstitusie geen religieus denominasionele koppeling aan die Huis van Oranje-Nassau nie, hoewel die dinastie formeel lidmate van die destydse Nederlandse Hervormde Kerk was. Koning Willem Frederik VI is byvoorbeeld in 1772 gedoop in De Grote Kerk in Den Haag (wat in 1574 ná die Reformasie die eiendom van die Nederlandse Hervormde Kerk geword het). Die Nederlandse Hervormde Kerk was in Nederland die 'bevoorrechte kerk'. Hierdie denominasie is egter nooit formeel 'staatskerk' genoem nie. Die 'bevoorregting' het in werklikheid op 'n informele 'staatskerk' neergekom. Die Nederlandse Hervormde Kerk is byvoorbeeld met staatsgeld gefinansier, omdat die instandhouding van die Hervormde Kerk 'door de overheid gezien [is] als openbaar belang' dat die 'christelijke hervormde Godsdiens' beskerm moet word. Die koning het volgens Artikel 139 van die konstitusie die reg gehad om beheer oor die kerk uit te oefen.

11.Die Edik van Versailles, ook genoem die Edik van Toleransie, was' $n$ poging om onverdraagsaamheid van die DL te ontlont en is deur die toedoen van die Roomse Franse koning Lodewyk XVI in 1787 uitgevaardig. Hierdie edik het godsdiensvryheid vir nie-Rooms-Katolieke gebied. Die Edik van Versailles was egter een van die vir nie-Rooms-Katolieke gebied. Die Edik van Versailles was egter een van die
belangrike bydraende faktore wat aanleiding gegee het tot die Franse Revolusie, belangrike bydraende faktore wat aanleiding gegee het tot die Franse Revol
en die daaropvolgende humanistiese antikerklike en antimonargale politiek. 
In 1864 het Kuyper met 'n lid van die parlement en van die Anti-Revolusionêre party, Groen van Prinsterer, begin korrespondeer. Van Prinsterer het Kuyper se politiek en teologie wesenlik beïnvloed (Schutte 1992:691). Kuyper het met die ortodokse stroming binne die Nederlandse Gereformeerde (Hervormde) kerk begin identifiseer. In 1886 het hy 'n eksodus uit die Nederlandse Hervormde Kerk gelei; hy kon nie langer met hierdie 'staatkerk' (volkskerk) saamleef nie. Hy wou nie aanvaar dat alleen die lede van die verbonds- of volkskerk tot die Christelike kerk behoort nie, maar almal wat God uitverkies. Hierdie uitverkiesdes (uitverkorenes) moes egter volgens die Kerkorde van Dordt georden wees en hulle 'verkosenheid' was met 'n dubbele uitverkiesingsleer (naamlik dat sommiges tot lewe en ander tot oordeel uitverkies is) gesanksioneer. Hierdie 'uitverkiesing', soos deur Kuyper geïnterpreteer, is dus hoegenaamd nie meer inklusief soos die 'uitverkiesing' in die kring van die verbondsvolk (volkskerk) - die Nederlandse Hervormde Kerk - verstaan is nie. Vir Hervormdes was al die dooplidmate van gelowige huisgesinne deel van die kerk, insluitende diegene wat lidmate van ander denominasies is. Daarom geld die 'oop' nagmaalsuitnodiging in die Hervormde Kerk, wat nie die geval in die Gereformeerde Kerke is nie. Een van die groot struikelblokke vir Kuyper, toe hy nog predikant van die Nederlandse Hervormde Kerk was, was dat die Hervormde Kerk verdraagsaam was ten opsigte van die interpretasie van die Reformatoriese leer en belydenis. Sy aandrang daarop dat predikante en lidmate die belydenisskrifte konfessioneel onkrities interpreteer en onderskryf, lei tot sy uiteindelike vertrek uit die Nederlandse Hervormde Kerk wat aanleiding gee tot die doleansie van 1886 en die stigting van die Gereformeerde Kerke.

In Nederland is die 'vrye kerk'-idee gebore toe Hendrik de Cock in 1834 van die Nederlandse Hervormde Kerk afgestig het. De Cock wou die leer van die Sinode van Dordrecht in ere herstel (vgl. Schutte 1992:691). Die 'vrye kerk-idee' het later belangrik begin word vanweë Kuyper se prorepublikeinse en antimonargale sentiment (kyk Kuyper 1911-1912:191-202). Hy het die 'liberale stroom' in die Nederlandse Hervormde Kerk geopponeer en het sodoende die neo-Calvinisme verder bestendig. Teenoor Frankryk se 'soewereiniteitsbegrip' waar 'regte' by die individu begin, en Duitsland se staatsoewereiniteit, het Kuyper geargumenteer ten gunste van aparte soewereiniteit, waarin organisasies soos skole, universiteite, die pers, en die industrie as 'soewerein' in eie reg/sfeer kon werksaam wees. Hy het baie hard gewerk om die ideaal van 'n demokratiese kerk wat onafhanklik van die staat is, te laat realiseer (Vree 2006:71; vgl. Molendijk 2008:238).

In 1899 het Kuyper by Princeton in die New Jersey, VSA, sy idees van 'n 'vrye kerk' uiteengesit. Tydens hierdie lesings het hy geargumenteer dat 'Calvinisme' meer as teologie is - dat dit eintlik 'n uitgebreide werklikheidsverstaan en wêreldverstaan is wat polities ' $n$ positiewe invloed op die ontwikkeling van organisasies en die samelewing uitoefen. Peter Heslam, verbonde aan die London Institute for
Contemporary Christianity, beskryf Kuyper se 'vrye-kerk'propaganda in sy Stone Lectures in 1899 by die Princeton Theological Seminary (kyk Langley 1999) soos volg:

The serenity with which Kuyper formulated his ideas on this matter in Princeton belies the fierceness of the controversy in which they were forged. The Belgic Confession [Nederlandse Geloofsbelydenis], to which both the Reformed (or Gereformeerde) churches ... owed allegiance, conceded in its Article 36 that the civil magistracy had the right to 'protect the sacred ministry' and, thus, to 'remove and prevent all idolatry and false worship.' During the 1890s Kuyper repeatedly proposed that this latter phrase - to 'remove and prevent all idolatry and false worship' - should be eliminated from the Article, but his proposal was bitterly opposed by his former colleague at the Free University, P. J. Hoedemaker [kyk Delfgaauw 1963:132-141], who held to a theocratic understanding of the role of the State in matters of religion. Although, [Hoedemaker] argued, Church and State were organizationally independent, the government was bound in its actions to the confession of the national Church ['volkskerk']. Conversely, the national Church ['volkskerk'] was bound to instruct the government, where necessary, on the formulation of policy. In opposition to Kuyper, he insisted that the State could know and recognize the Church as the Church - as the divinely instituted revelation of the body of Christ on earth [kyk Hoedemaker 1901]. (Heslam 2002:21).

Die afskeidingsbeweging deur ortodokse konfessioneles en teenkanting teen beweerde liberale teologie in Nederland het later as die Gereformeerde Kerke bekend gestaan. Die tendens wat spesifiek as 'liberaal' uitgewys is, die sogenaamde 'kollegialisme' wat in die kerkreg (in Nederland en SuidAfrika) vorendag gekom het toe die Algemeen Reglement deur die sinode van die Nederlandse Hervormde Kerk in 1851 aanvaar is. Die Gereformeerdgesinde konfessioneles het hierdie 'liberale teologie' gesien as afwyking van die DL wat tydens die Sinode van Dordrecht gedurende 1618-1619 opgestel is (kyk Torfs et al. 2003:220).

Die ander stroom wat aangesluit het by die Remonstrante se interpretasie van Calvyn se leer (spesifiek die uitverkiesingsleer soos dit uitgekristalliseer het) het in Leiden begin. Hierdie denkrigting is in Utrecht en Groningen voortgesit. Die Remonstrante het in Leiden en Utrecht hulle ampsvoorregte in die 'bevoorregte' volks- (staats-) kerk uitgeoefen, ten spyte van hulle ekskommunikasie uit die kring van die neo-Calvinistiese georienteerdes. Hierdie nawerking het ineengevloei met die totstandkoming van die etiese teologie, waarvolgens gekies is vir die 'derde opsie', wat beteken: geen onverdraagsame konfessionalisme en belydenisdwang nie, maar ook nie vrye liberalisme nie, gemotiveer deur humanitêre politiek, beïnvloed deur die Franse Revolusie wat antikerklik en daarom ook antidogma was.

Die gedagtes van individuele dominees met Remonstrantse agtergrond is in die etiese teologie getransformeer. Die dolerende Gereformeerde Kerke Nederland (GKN) het, deur die stigting van die Vrije Universiteit Amsterdam, Kuyper en Bavink se denke bevorder teenoor die teologiebeoefening by die Rijksuniversiteite in Leiden, Groningen en Utrecht. 
Hierdie Rijksuniversiteite het die teologiese baarmoeder van die Nederlandse Hervormde Kerk gevorm - veral vir die etiese teologie georïenteerdes onder hulle (kyk later). Die dolerendes het hulle kerkorde ingerig na aanleiding van die Kerkorde van Dordtrecht, 1819, en veral soos dit in 1854 gewysig is. Die dolerendes was antimonargaal en daarom anti-Hervormde Kerk en anti-volkskerk.

Die Hervormde etiese teoloë se herkoms spruit voort uit die gees van toleransie soos uitgedruk in die Algemeent Reglement van 1816. Die Nederlandse Hervormde Kerk het 'n 'kollegiaal-presbiteriale' kerkwet na aanleiding van die Algemene Reglement van 1816 gehad. Die NHKA het dit geërf en hierdie kollegiale plus presbiteriale klem het in die NHKA se kerkorde neerslag gevind tot en met die 1997-Kerkorde van die NHKA.

\section{'n Derde baan van ontwikkeling}

Te midde van 'n bepaalde liberale modernisme en 'n Gereformeerde ortodoksie, ontwikkel daar 'n derde benadering - 'n derde opsie (Loader 1987:47-55; 1989:432) wat as 'etiese teologie' bekend staan en só deur Daniel Chantepie de la Saussaye (1818-1874) beskryf is. Hierdie teologie het ontwikkel as ' $n$ benadering tot die verstaan van 'waarheid' waarin waarheid nie in proposisies vasgevang kan word nie en nie gerasionaliseer kan word nie (Loader 1987:48). Dit was nie 'n teologie wat na sedelikheid of moraliteit verwys het nie (contra Bavinck 1903:25) of 'eties' toegepas kan word of moes word nie. Alhoewel dit in die konteks van 'n bepaalde liberale modernisme en gereformeerde ortodoksie (oftewel 'n onkritiese konfessionele teologie) as benadering ontwikkel het, was dit nie 'n bemiddeling (kompromis) tussen geloof en rede nie, of tussen konfessie en kognitiewe rasionaliteit nie (Van Aarde 2012:5 van 14). Op die spoor van soortgelyke insigte as dié van Philippus Melanchthon, die 'brugbouer' (Van der Pol 2011), beklemtoon etiese teologie op dialektiese wyse geloof én rede. Daniel Chantepie de la Saussaye, wat in Leiden (tuiste van die Remonstrante) gestudeer en professor in Groningen was, en J.H. Gunning (1829-1905) wat in Utrecht gestudeer het en in Amsterdam professor was, was die grondleggers van die etiese teologie. Latere Hervormde teoloë, wat vanuit hierdie paradigma teologie beoefen het en 'n wesenlike invloed op die teologie van die Nederduitsch Hervormde Kerk gehad het, was Barend Gemser (1890-1962) en Adrianus van Selms (1906-1984) ${ }^{12}$.

Hulle het van die oortuiging uitgegaan dat waarheid nie in konsepte of voorstellings vasgevang kan word nie - dit kan alleen 'ontmoet' word (Loader 1988:48). Vanuit hierdie paradigma is geloof 'n lewenswyse (Van Aarde 2012:5 van 14; vgl. Loader 1987:48-49) wat hart en verstand omvat. Dit beteken 'n wetenskaplike (kritiese) teologie waarin Bybelse verhale mense help in hulle lewenstryd tussen geloof en vrees, en die geloofsbelydenisse die getuienis van gelowiges se geloofstryd is - 'n grammatika van geloofstaal. Dit beteken die 'hart' - die konfessie, die belydenis van geloof of die verstand kon nie op sigself 'uitkom' by waarheid nie - wat aanhoudend ontvou en telkens weer ontmoet word.

\section{Die dekonstruksie van die Dordtse Leerreëls se grammatika van 'uitverkiesing': 'n Herbesoek aan Calvyn se uitverkiesingsleer}

In die post-Reformasie tydperk het ' $n$ bepaalde skolastiese benadering tot teologiebeoefening ingetree. Die insigte van die Reformatore is ontwikkel deur 'n sistematiese aanbod van Christelike teologie. Die beginpunt van hierdie teologiese ontwikkeling was bepaalde beginsels, dit wil sê kerkleer. Die periode tussen 1559 en 1622 is gekenmerk deur 'n beklemtoning van suiwer leer (vgl. McGrath 2001:78) en die sistematies teologiese uitwerk van die inhoud van die belydenis. Die Calvinisme wou sigself enersyds van die Lutherse tradisie, sowel as van die Rooms-Katolieke tradisie onderskei. Dit is in hierdie konteks (met al die bogenoemde in ag genome) dat Calvyn se leer van die uitverkiesing verder ontwikkel is.

Die verstaan van die begrip 'uitverkiesing' deur Calvyn vind neerslag in beide die NGB en in die DL. Hierdie interpretasie van 'uitverkiesing' (predestinasie) kan nie los van die vroeëre Rooms-Katolieke kerklike eksklusiwisme begryp word nie. In die teologiegeskiedenis het dit tot 'n soort onverbiddelike 'uitverkiesingsdogma' ontwikkel, veral deur die toedoen van die latere 'neo-Calvinisties-skolastiese' onverdraagsaamheid. Vir die hervormers het Calvyn se verstaan van 'God se uitverkiesing' die bedoeling gehad om teenoor Roomse eksklusiwisme te beklemtoon dat Protestante óók by God se genade en 'uitkies' van die mensdom ingesluit is. Dordt se interpretasie (gegrond op Calvyn en NGB s'n) was gemik op die handhawing van 'suiwere Calvynse leer' - teenoor die moontlike distorsie daarvan of ' $n$ terugkeer na enigiets wat sou neerkom daarop dat die mens met God se genade (uitverkiesing) kan inmeng. So gesien, is God se 'uit-kies' die taal (voertuig) waarin die mens God se onverdiende genade metafories geklee en vervoer het (dit verpak het). 'Kies' is dus menslike taal, 'n metafoor vir 'genade'. Dit is soos om te sê die 'kerk is die huis van God' of 'God is soos 'n vader'. God se genade is 'kies'.

In die boek van David S. Chen (2008), Calvin's passion for the church and the Holy Spirit, sê Chen:

In accordance with the teaching of the Scriptures, Calvin thus taught that God's election is founded on his [God's] goodness and mercy, without regard to human worth. If God chose some and rejected the rest, how can the reprobate be held responsible for what they are and how can the love of God be reconciled to the destruction of the reprobate? These are difficult question[s] to answer, but Calvin's answered them with a conviction that on one hand God must be glorified for man's [humankind's] salvation and on the other hand men's [human beings'] rejection of salvation which must be regarded as his [/her] own responsibility, and not that of God. (Chen 2008:287). 
Calvyn se verstaan van God se keuse vír die gelowige en die keuse van die afvallige (reprobate) téén God se wil om vir alle mense te kies, kan nie sonder Calvyn se beklemtoning van die werk van die Heilige Gees verstaan word nie. Chen (2008:290) formuleer hierdie siening van Calvyn soos volg:

Calvin believed that, even though God allowed the reprobate to reject him [God], his [God's] complete control over all things by his [God's] Spirit ever remains. Calvin exalted the sovereignty of the Spirit to the point of saying that even the elect can never know their own election and salvation without the illumination of the Spirit.

Calvyn was in beginsel verdraagsaam jeens alle mense. Sy verdraagsaamheid het wel perke omdat hy 'n verskil tref tussen 'waarheid' en 'leuen' (kyk Calvin [1847-1850a] se eksegese van Esegiël 13:9). Calvyn kan verdraagsaam wees omdat hy bewus is daarvan dat daar verskillende perspektiewe op die 'waarheid' is (immers, hy en Luther het nie oor alles saamgestem nie). Daarom, op grond van Calvyn [1847-850b] se eksegese van die metafoor 'geknakte riet' in Jesaja 42:3, is Calvyn van oortuiging dat God nie wil hê dat die mens die 'geknakte mens', dit wil sê die persoon wat 'n ander perspektief op die 'waarheid' het, moet breek nie. Daarom geld Calvyn se verdraagsaamheid vir die lidmate van die RKK. Wat die RKK betref, meen hy egter wel dat die leierskap (pous en kardinale) as 'anti-Christelik' gereken behoort te word, omdat hulle nie bloot 'n ander perspektief op die 'waarheid' het nie, maar vir die 'leuen' propaganda maak (Calvin [2002]:3-24, 25-71).

Calvyn se geloof in God se onwrikbare alleenheerskappy (soewereiniteit) was die basis van die leer oor uitverkiesing en voorsienigheid wat hy ontwikkel het. Sonder voorsienigheid sou die lewe vir mense onleefbaar gewees het en sonder uitverkiesing sou niemand verlos kon word nie. Calvyn het gemeen God 'sien' en 'weet' wat met die mensdom aangaan - dat God ten nouste betrokke is by die mensdom (Inst. 1.16.2-3.8). Oor uitverkiesing (Inst. 3.22.10, 3.21.1) het Calvyn gestel dat God se keuse vír die mensdom aan almal 'beskikbaar gestel word' en dat almal dit hoor, maar dit word nie deur almal geïnternaliseer of deur almal aanvaar nie. Indien ons Calvyn se siening sou interpreteer dat dit sou neerkom op 'n eksklusiewe verstaan van uitverkiesing van God se kant af, sal ons ons menslike selfhandhawende en selfsugtige verstaan van 'kies' gelyk stel aan God se 'kies'. Die metafoor 'kies' word gebruik om God se 'kies' (genade) te verwoord, maar hoe mense 'kies' en hoe God 'kies', is nie dieselfde nie. Dit kom dus daarop neer hoe mens God se 'kies' verstaan - en in die konteks van Calvyn se skrywes was God se kies (genade) vir almal. Hoe Calvyn se skrywes en leer later verstaan en geïnterpreteer is, is 'n heeltemal ander saak as die bedoeling daarvan binne die konteks waarin dit ontstaan het.

\section{Ten slotte: 'n Grammatika van geloofstaal}

As dogmatiek (die konfessie of belydenis) die grammatika (die taal) is van die saak (geloof), dan kan die taal self (dit is ook die konteks) nie afdwingende gesag beklee nie, want die taal is die middel waardeur die 'saak' gestel word. Die dogmatiek self het nie afdwingende gesag nie; die 'saak van die evangelie' dring ons egter wel om eties te handel. In hierdie opsig is Dordt en die taal waarmee God se genade daarin verwoord is, te verstane in die tyd en plek waartydens dit ontstaan het. Die saak van 'Dordt', op die spoor van die 'saak' wat Calvyn ook wou verwoord, is onverdiende genade. Dit is vandag vir Reformatoriese gelowiges steeds die kern. Die Dordtse Leerreëls kan net 'eenkant' geplaas word indien 'genade' nie meer deel is van die kern van hoe die 'saak' van die evangelie verstaan word.

Ons kan ons hedendaagse geregverdigde inklusiwiteitsdenke nie ondersteun deur 'n teologie van onvoorwaardelike aanvaarding van alle mense deur God in die konteks van die Dordtse Reelreëls in te dra nie. Inklusiwiteit-eksklusiwiteit in die sosio-politieke konteks van die opkoms van nasionalisme en die nasie-staat is nie dieselfde as in ons tyd van 'transnasionale' globalisasie, ekumene en gesekulariseerde samelewing nie. Die 'gees' van Dordt behoort eerder in terme van die sosio-politieke konteks van daardie tyd ernstig opgeneem word. Die Remonstrante se optimistiese mensbeeld (versus die neo-Calvinistiese pessimistiese siening oor die onvermoë van die mens) het nie, soos op die Sinode van Dordrect geargumenteer is, ontken dat die mens beperk is om uit sigself te weet wat goed is nie. Dit wou wel die moontlikheid oophou dat die mens uit eie hart én rede die wens koester om te bly soek na die waarheid. Is dit werklik in stryd met NGB, Artikel $15^{13}$, wat bely dat mens selfs vóór geboorte nie dieselfde vermoë as God het nie en dat die doop ook nie aan die mens so 'n magiese goddelike vermoë gaan verskaf nie? Om in hierdie sondeleer 'n algehele pessimisme in te lees, is haatdraend teenoor veral babatjies as 'verlore' of 'gered', sonder dat hulle nog kan 'weet' of 'vertrou'14, en die mens op psigologiese wyse van enige positiewe selfbeeld te ontneem, is nie billike eksegese nie. Onbillike eksegese sal die Dordtse Leerreëls in teenspraak met beide die Heidelbergse Kategimus en die Nederlandse Geloofsbelydenis stel, om nie eens te praat van in teenspraak met die evangelie nie!

Die volslae verlorenheid van die mens wat die Dordtse Leerreëls leer, is ook nie in stryd met die 'toleransie'beginsel van NGB Artikel 16 nie. Volgens hierdie 'basisteks' van Dordt (NGB 16) word vertel dat 'Adam' se ongehoorsaamheid in alle mense aanwesig is, maar dat God, deernisvol en genadig, vir die mens in en deur Jesus Christus kies; en diegene wat hulle rug op Jesus Christus draai, verworpe is omdat hulle vir hulle eie verdoemenis verantwoordelik is. Om te beweer dat Dordt hiermee sal leer

13.Die eksegese van proposita in die $\mathrm{DL}$ hierbo en die intertekstuele vergelyking van proposita in die DL met dié in die HK en NGB wat volg, is gegrond op die resente kritiese edisie van die DL, naamlik dié van Sinnema, Moser and Selderhuis (2014).

14.Dit is die rede waarom Karl Barth (Barth 1969, KD III.4.275; Barth 1967, KD IV.4.112) nie net teen die idee dat die kerk' $n$ volkskerk of verbondskerk is, gekant was nie mar ook nie ten gunste van die doop van babatjies was nie (vergelyk was nie, maar ook nie ten gunste van die doop van babatjles was nie (vergelyk Hunsinger 2000:254-256). Berkouwer (1947.110-111) en Van Ruler (1945:85-86) met sy kritiek op die 'volkskerk' op did . Volgens Beop in verband gesien moet word met sy kritick op die 'volkskerk'-idee. Volgens Berkouwer (1947:41-51) is dit Barth se oortuiging dat die verhouding doop-kinders-predistinasie as ' $n$ 'volksmassa-kerk projectie' gesien kan word. 
dat die mens geen sosiale barmhartigheidstaak het nie en dat daar geen sin is om vir korrekte etiek te ywer nie, neem nie die 'nawerkingsgeskiedenis' van Dordt in ag nie, soos dit uitmuntend in die Mennoïtiese Christelike kerk aangetref word nie.

Eweneens maak Dordt se leer oor die plaasvervangende offerdood van Christus nie die sosiale verantwoordelikheid van die mens tot niet nie. In hierdie opsig is Dordt op sowel die NGB (Artikel 21) as die Heidelbergse Kategismus (Sondagsafdeling 15 en 16) gegrond. Dit neem nie weg dat ons vandag weet dat die Heidelbergse Kategismus méér op Anselmus se satisfaksieleer as op Paulus se teologie teruggaan nie. Daarom moet daar met nuanse onderskei word tussen die Ou-Testamentiese offerteologie en die Middeleeuse middelaarsteologie, en die dispuut tussen die RKK en die Reformatoriese regverdigheidsleer. Om die Remonstrante se teensin teen die neo-Calvinisme se eensydige sondeleer as 'Satanswerk' te bestempel, gaan te ver en bevestig net die onverdraagsaamheid van daardie tyd.

Volgens NGB, Artikel 27, bestaan die ware kerk alleen uit 'ware Christen-gelowiges'. Dit is die anderkant van dieselfde muntstuk as die RKK wat vóór die Tweede Vatikaanse Ekumeniese Konsilie geleer het dat daar geen saligheid buite die RKK is nie. Sonder dat die Konsilie van Trent en die Eerste Vatikaanse Konsilie uit die geskiedenisboeke verwyder word, is ons bewus dat sowel die RKK as die Protestantse ekumene vandag nie so 'n streng eksklusiewe teologie huldig nie.

Die Dordtse Leerreëls se 'gees' en historiese konteks behoort in ag geneem te word wanneer Artikel 3, naamlik dat God God se eiendom teen die aanvalle van Satan beskerm, gelees word. Artikel 6 sê dat ek as gelowige in sonde geval het, God wel toelaat dat ek steeds kan glo. My weergebore-wees is volgens Dordt 'n proses: ouers (vervang dit ook met 'naaste') raak bewus van God se werking in my lewe en ek ervaar die effek van die werk van die Heilige Gees in my lewe (Artikel 12). Hierdie proses gaan ons begrip te bowe. Al wat ek uit geloof agterna kan sê, is dat ek God se Woord aanvaar het (DL, Artikel 13 en 16).

Toegegee, hierdie 'prosesteologie' is in Dordt in die 'grammatika' van goddelike voorkeur gegiet. Maar as 'n mens die 'gees van politieke en godsdienstige onverdraagsaamheid' in die konteks van die Spaans-Habsburgse-Nederlandse nasionalisme en nasie-staat verstaan, kan ons by die onverdraagsaamheid verby beweeg en die Heilige Gees se proses van bewusmaking van genade positief waardeer. Ons doen dieselfde met byvoorbeeld die Israelitiese etnosentriese Sionsteologie en die boek Prediker se negatiewe mensbeeld wat meen dat alles ' $n$ fatalistiese gejaag na wind is. Ons haal nie hierdie boeke uit die Bybel nie, maar sien dit as deel van die wyse waarop die Heilige Gees ons bewus maak van God se 'transnasionale', onvoorwaardelike en radikaal inklusiewe liefde vir alle mense. Ons besef nou dat Paulus op grond van hierdie evangelie die vaste oortuiging het dat die Christengelowige eties op dieselfde wyse optree teenoor medegelowiges as teenoor nie-Christene. Ons hoef daarom nie die Dordtse Leerreëls uit ons kerkgeskiedenis te verwyder sodat ons steeds vandag die liefdevolle verkiesing van God van alle mense in en deur Jesus Christus met volle oortuiging van ons kansels kan verkondig en in die praktiese etiek uit kan leef nie. Die volgehoue behoud van die Dordtse Leerreëls help ons om die futiliteit van nasionalisme as middel tot saligheid, van die etiese onaanvaarbaarheid van etniese eksklusiwisme en selfverryking (ondersteun met eksploitasie van mense se ekologiese en sosiale ruimtes) skerper te verstaan.

Inderdaad gaan die gebruik van die proponentsondertekeningsformule terug na die Sinode van Dordtrecht. Ons behoort egter te onthou dat ons nie met hierdie 'formule' bevestig dat elke stelling in volkome ooreenkoms met die Heilige Skrif is nie. Wat ons in die 'formule' sê, is dat ons vas van oortuiging is dat die leer wat in die belydenisskrifte voorkom, volkome met die Heilige Skrif ooreenkom. Hierdie leer is die saak van die belydenisskrif - die saak (proprium) wat ons eers ontdek nadat ons die menslike, destydse sosiopolitieke-godsdienstige kultuur waarbinne hierdie saak (leer) in 'n propositum tot uitdrukking gebring is - van die saak (proprium) onderskei, hoewel die saak nie van die kulturele bedding geskei kan word nie. Eers as die saak (leer) van die belydenisskrif in botsing is met die saak van die evangelie van Jesus Christus, behoort ons daarop aan te dring dat dit gewysig en selfs geskrap behoort te word.

Die drie Reformatoriese Formuliere van Eenheid (die HeidelbergseKatgesismus, dieNederlandseGeloofsbelydenis en die Dordtse Leerreëls) bevat 'n goue draad wat daardeur vleg. En dit is dieselfde boodskap as dié van Paulus, naamlik dat ons alléén uit geloof gered word - dat enige vertroue op die menslike natuur of op dit wat geskape is, ook nie die kerk as instituut en abstrakte geloofsartikels (proposisies) nie vir die mens ' $n$ hoopvolle toekoms kan bied nie. Inteendeel, net verwerping en verlorenheid. Dit is die vrye, soewereine God wat genadig en vol liefde is, wat ons hoop en basis van geloof is. En soos die nawerkingsgeskiedenis van die Dordtse Leerreëls dit uitwys, bring hierdie liefdevolle verkiesende daad van God die mens uit by sosiale en etiese verantwoordelikheid.

\section{Erkenning}

Hierdie artikel word opgedra aan dr. Christo van der Merwe uit erkentlikheid vir sy bydrae tot die teologie van die Nederduitsch Hervormde Kerk.

\section{Mededingende belange}

Die outeur verklaar dat sy geen finansiële of persoonlike verhouding(s) het wat haar op 'n voordelige of nadelige wyse in die skryf van die artikel beïnvloed het nie.

\section{Literatuurverwysings}

Bakhuizen van den Brink, J.N. \& Dankbaar, W.F., 1967, Handboek der kerkgeschiedenis, Deel III: Reformatie en Contra Reformatie, Bert Bakker, Daamen N.V., Den Haag. 
Barth, K., 1967, 'Die Taufe als Begründung des christlichen Lebens', in K. Barth (Hrsg.) Die kirchliche Dogmatik, IV.4, EVZ-Verlag, Zürich.

Barth, K., 1969, 'Die Lehre von der Schöpfung', in Die kirchliche Dogmatik, III.4, 3. Auflage, EVZ-Verlag, Zürich.

Bavinck, H., 1903, De theologie van Prof. Dr. Daniel Chantepie de la Saussaye, Bijdrage tot de kennis der ethishe theologie, 2e druk, Donner, Leiden.

Berkouwer, G.C., 1947, Karl Barth en de kinderdoop, Kok, Kampen.

Bierma, L.D., 2013, The theology of the Heidelberg Catechism. A reformation synthesis, Westminister John Knox Press, Louisville, KY.

Bijleveld, N.H., 2007, 'Voor God, volk en vaderland: de plaats van de Hervormde predikant binnen de nationale eenwordingsprocessen in Nederland in de eerste helf van de negentiende eeuw', PhD Proefskrif, Universiteit van Groningen.

Blei, K., 2006, The Netherlands Reformed Church, 1561-2005, transl. A.J. Jannsen, Eerdmans, Grand Rapids, MI.

Calvin, J., 1847-1850a, Calvin's commentaries, vol. 23: Ezekiel, Part II, Section 11, transl. J. King, 1847-1850, viewed 16 May 2015, from http://www.sacred.texts.com

Calvin, J., 1847-1850b, Calvin's commentaries, vol. 15: Isaiah, Part III, transl. J. King, 1847-1850, viewed 16 May 2015, from http://www.sacred.texts.com

Calvin, J., 2002, Calvin's tracts relating to the Reformation, with 'His [Calvyn s'n] life' by Theodore Beza, vol. 1, 2002, 'Letters by James Sadolet, a Roman cardinal, to the senate and people of Geneve', pp. 3-24, [and] Reply by John Calvin', pp. 25-71, senate and people of Geneve', pp. 3-24, [and] Reply by John Calvin',
transl. H. Beveridge from the original Latin, Wipf \& Stock, Eugene, OR.

Chen, D.S., 2008, Calvin's passion for the church and the Holy Spirit, Xulon Press, Maitland, FL.

Clarke, R.S., 2008, 'The Canons of Dort', Table Talk Magazine, 01 April 2008, viewed 02 May 2015, from http:// www.ligonier.org/learn/articels/canons-dordt/

Clemens, Th., 1998, 'Confessie, kerk, natie en staat in Nederland', in J. de Bruijn (red.), Geen heersende kerk, geen heersende staat: De verhouding tusssen kerken en staat 1796-1966, pp. 145-176, Meinema, Zoetermeer.

Coertzen, P., 2012, 'Dordt and South Africa: The nature and challenges for Reformed Church polity in South Africa', Nederduitse Gereformeerde Tydskrif 53(3/4), 7889. http://dx.doi.org/10.5952/53-3-4-252

De Groot, A., 1993, 'Het Algemeen Reglement van 1816', in J.H. Van den Bank \& F.G.H. Broeyer, (eds.), Theologie en kerk in het tijdperk van de Camera Obscura: Studies
over het Nederlandse protestantisme in de eerste helft van de negentiende eeuw, over het Nederlandse protestantisme in de eerste helft van de negentiende eeuw,
pp. 111-137, Departement Godgeleerdheid van de Universiteit Utrecht, Utrecht pp. 111-137, Departement Godgel
(Utrechtse Theologische Reeks 18).

Delfgaauw, G.J.J.A., 1963, De staatsleer van Hoedemaker: Een bijdrage tot de kennis van de christelijk-historische staatsopvatting, Kok, Kampen.

Dreyer, W.A., 2006, 'Die Nederduitsch Hervormde Kerk van Afrika as volkskerk: Oorsig en herbesinning', HTS Teologiese Studies/Theological Studies 62(4), 1337-1368. http://dx.doi.org/10.4102/hts.v62i4.415

Dreyer, W.A., 2014, 'The Heidelberg Catechism: A 16th century quest for unity', HTS Teologiese Studies/Theological Studies 70(1), Art. \#2092, 5 pages. http://dx.doi. org/10.4102/hts.v70i1.2092

Fix, A.C., 1991, Prophecy and reason: The Dutch collegiants in the early Enlightenment, Princeton University Press, Princeton, NJ.

Goudriaan, A., 2011, 'The Synod of Dordt on Arminian anthropology', in A. Goudriaan \& F. Van Lieberg (eds.), Revisiting the Synod of Dordt (1618-1619), pp. 81-106, Brill, Leiden (Brill's Series in Church History, Vol. 49).

Harder, T., 1995, Spiritual life in Anabaptism, translated and edited by C.J. Dyck, Herald Press, Scottdale, PA, viewed 16 May 2015, from http://www.goshen.edu/mqr/ pastissues/oct04harder.html

Heron, A.C., 1980, A century of Protestant theology, Westminster, Philadelphia, PA.

Heslam, P.S., 2002, 'Prophet of a third way: The shape of Kuyper's socio-political vision', Journal of Markets \& Morality 5(1), 11-33. http://www.acton.org/ publications/mandm/mandm_article_72.php

Hoedemaker, Ph. J., 1901, Artikel 36 onzer Nederduitsche geloofsbelijdenis tegenover Dr. A. Kuyper gehandhaafd, Van Dam, Amsterdam.

Hunsinger, G., 2000, 'Baptism and the soteriology of forgiveness', International Journal of Systematic Theology 2(2), 247-269. http://dx.doi.org/10.1111/14631652.00039

Jonker, W.D., 1994, Bevrydende waarheid, Hugenote Uitgewers, Wellington.

Kamphuis, J., 1988, 'Sinode van Dordrecth liep niet vas in steeg van verkiezingsfatalisme', Reformatorisch Dagblad, 28 december 1988, geraadpleegd op 24 april 2015 van http://www.digibron.nl/search/detail/b1dfc65ecec1c5c867d0e9769129bbd/ synode-van-dordt-liep-niet-vast-in-steeg-van-verkiezingsfatalisme

Kendall, R.T., 1979, Calvin and the English Reformation to 1949, Oxford University Press, New York, NY.

Kugler, T., 2015, 'State-sponsored religion as impediment to assimilation and immigration', in . Quezada-Grant \& S. Donabed (eds.), Narratives and negotiation: Agency, religion and state, pp. 240-255, Lexington Books, New York, NY.

Kuyper, A., 1911-1912, Pro Rege of het koningschap van Christus, II-III, Kok, Kampen.

Landau, P., 2010, Grundlagen und Geschichte des evangelischen Kirchenrechts und desStaatskirchenrechts (Ius Ecclesiasticum 92), Mohr Siebeck, Tübingen.
Langley, M.R., 1999, 'Abraham Kuyper: A Christian worldview', New Horizons, January 1999, viewed 10 May 2015, from http://www.opc.org/new_horizons/NH99/ NH9901d.html

Loader, J.A., 1987, 'Tertium datur - oor die etiese waarheidsbegrip', HTS Teologiese Studies/Theological Studies 43(1/2), 47-57.

Loader, J.A., 1988, 'Die waarheid is eties: Oor die Skrifbeskouing van die Etiese Teologie', In Luce Verbi 22(1), 42-55.

Loader, J.A., 1989, 'Ontstaan en eerste periode van die Hervormde Teologiese Opleiding aan die Universiteit van Pretoria', HTS Teologiese Studies/Theological Studies 45(1), 412-432. http://dx.doi.org/10.4102/hts.v45i2.2284

McGrath, A.E., 2001, Christian theology. An introduction, Blackwell, Oxford.

Molendijk, A., 2008, 'Neo-Calvinist cultural Protestantism: Abraham Kuyper's Stone lectures', Church History and Religious Culture 88(2), 235-250. http://dx.doi. org/10.1163/187124108X354330

Moxnes, H., 2012, Jesus and the rise of nationalism, I.B.Tauris \& Co., London.

Pelser, G.M.M., 1999, 'Die vraag na die noodsaaklikheid van 'n eietydse belydenis: Nuwe Testamenties en eksegeties beoordeel', HTS Teologiese Studies/Theological Studies 55(2/3), 417-436. http://dx.doi.org/10.4102/hts.v55i2/3.1592

Pelser, G.M.M. \& Van Aarde, A.G., 2007, 'Historical consciousness and existential awareness in Karl Barth's hermeneutics', HTS Teologiese Studies/Theological Studies 63(4), 1377-1411. http://dx.doi.org/10.4102/hts.v63i4.268

Pettegree, A., 2002, Europe in the sixteenth century, Blackwell, Oxford.

Pont, A.D., 1986, 'Verbond en volkskerk', HTS Teologiese Studies/Theological Studies 42(1), 28-76. http://dx.doi.org/10.4102/hts.v42i1.2128

Ricoeur, P., 1974, 'Philosophische und theologische Hermeneutik', in P. Ricoeur \& E. Jüngel (Hrsg.), Metapher: Zur Hermeneutik der religiöser Sprache, pp. 2-24, Chr Kaiser Verlag, München.

Schaff, P., 1983, The creeds of Christendom, volume I: The history of Creeds, Baker Books, Grand Rapids, MI.

Schutte, G.L., 1992, 'Nederland: Een calvinistische natie?', BMGN-Low Countries Review 107(4), 690-702, geraadpleegd op 24 april 2015 van https://www. google.co.za/search?q=dspace.library.uu.nl\%2Fbitstream\%2F...\%2F3594-6981-1PB.pdf

Sinnema, D., Moser, C. \& Selderhuis, H. (eds.), 2014, Acta et Documenta Synodi Nationalis Dordrechtanae (1618-1619), Vandenhoeck \& Ruprecht, Göttingen.

Sinnema, D.W., 2011, 'Calvin and the Canons of Dordt', Church History and Religious Culture 91(1/2), 87-103. http://dx.doi.org/10.1163/187124111X557782

Thorson, S., 1994, 'Tensions in Calvin's view of faith: Unexamined assumptions, in Kendall, R.T., Calvin and English Calvinism to 1649', Journal of the Evangelical Theological Society 37(3), 413-426.

Torfs, R., Martens, K., Koffeman, L.J.\& Coertzen, P., 2003, Recht op recht in de kerk, Peeters, Leuven. (Canon Law Monograph Series).

Van Aarde, A.G., 2012, "n Postliberale perspektief op 'n ekklesiologiese modaliteit as 'n ecclesiola in ecclesia - heroriëntasie in die Nederduitsch Hervormde Kerk van 'n ecclesiola in ecclesia - heroriëntasie in die Nederduitsch Hervormde Kerk van Afrika', HTS Teologiese Studies/Theological St
http://dx.doi.org/10.4102/hts.v69i1.2012

Van der Merwe, C., 1997, 'Missionêre gerigtheid van die kerk', HTS Teologiese Studies/ Theological Studies 55(3), 705-721.

Van der Merwe, C., 2013, 'Lense op spiritualiteit en kerkwees: die pad vorentoe vir die Nederduitsch Hervormde Kerk van Afrika', HTS Teologiese Studies 69(1), Art. \#1988, 16 bladsye. http://dx/doi.org/10.4102/hts.v69i1.20143

Van der Merwe, C., 2014, "n Narratief vir kerk-wees vandag', HTS Teologiese Studies/ Theological Studies 70(1), Art.\#2699, 13 bladsye. http://dx/doi.org/10.4102/hts. v70i1.2014

Van der Pol, F. (ed.), 2011, Philippus Melanchthon: Bruggenbouwer, Kok, Utrecht.

Van Eijnalten, J., 2003, Liberty and concord in the United Provinces: Religious toleration and the public in the eighteenth-century Netherlands, Brill, Leiden.

Van Ruler, A.A., 1945, 'Kerk en verbond', in A.A. van Ruler, Religie en politiek, bl. 69-86, Callenbach, Nijkerk.

Van Wyk, T., 2012, 'Kerkwees in die saeculum vandag, Deel 1: Eenheid te midde van veelheid', HTS Teologiese Studies/Theological Studies 68(1), Art. \#1281, 9 bladsye. $\mathrm{http}: / / \mathrm{dx}$.doi.org/10.4102/hts.v68i1.2012

Van Wyk, T., 2014, 'Nasie, volk, religie en kerk as ellips van versoenende verskeidenheid', HTS Teologiese Studies/Theological Studies 70(3), Art. \#2671, 10 bladsye. http://dx.doi.org/10.4102/hts.v70i3.2014

Vorster, J.M., 1999, An introduction to Reformed church polity, Potchefstroom Theological Publications, Potchefstroom.

Vree, J., 2006, Kuyper in de kiem: De precalvinistische periode van Abraham Kuyper 1848-1874, Verloren, Hilversum.

VU University of Amsterdam, [1607] 2009, 'Brief aan Johannes Uytenbogaert/François van Aerssen', geraadpleegd op 21 mei 2015 van http://imagebase.ubvu.vu.nl/ getobj.php?ppn=34560358

Walker, W., 1970, A history of the Christian church, T. \& T. Clark, Edinburgh. 